Neskorodzhena Larisa, $\mathrm{PhD}$ (Law Sciences), Associate Professor, Kyiv National University of Trade and Economics, 19, Kyoto str., Kyiv, 02156, Ukraine

ORCID: 0000-0002-1484-3557

Researcher ID: M-3683-2016

\title{
PRACTICE OF THE ANTIMONOPOL COMMITTEE OF UKRAINE ON DEFINITION OF PUBLIC PROCUREMENT CONCEPTS
}

The article examines the practice of the Antimonopoly Committee of Ukraine on the application of the "two manufacturers» rule when considering complaints in the field of public procurement. Arguments about the illegal practices of the Antimonopoly Committee of Ukraine on the substitution of the terms «manufacturer» and «entity» are presented.

Keywords: public procurement, Antimonopoly Committee of Ukraine, manufacturer, entity.

Нескороджена Лариса. Практика Антимонопольного комітету Украӥни щодо визначення концепцій публічних закупівель.

В статті розглядається практика Антимонопольного комітету Украӥни щзодо застосування правила «двох виробників» при розгляді скарг в сфері публічних закупівель. Наводяться аргументи щодо незаконної практики Антимонопольного комітету України щодо підміни понять «виробник» та «суб'єкт господарювання».

Ключові слова: державні закупівлі, Антимонопольний комітет Украйни, виробник, суб' 'єкт господарювання.

Relevance of research topic. The Antimonopoly Committee of Ukraine under the Law of Ukraine «On Public Procurement» (Law Ukrainy, 2015) is the body of appeal in the field of public procurement. The Antimonopoly Committee of Ukraine, as a body of appeal, establishes a Permanent Administrative Board for the Consideration of Complaints of Violations of Public Procurement Law. In order to ensure the impartial and effective protection of the rights and legitimate interests of persons involved in the procurement procedures, the Permanent Administrative Complaints Board shall decide on the elimination of public procurement violations. The purpose of this article is to investigate the mandate of the Permanent Administrative Board to handle complaints of breaches of public procurement law. 
Formulation of the problem. When considering complaints about breach of public procurement law, the Permanent Administrative Board of the Antimonopoly Committee of Ukraine (hereinafter - the Board) very often applies the «two manufacturers» rule. However, in our opinion, the Board has replaced the concepts that are enshrined in the Law of Ukraine «On Public Procurement» (Law Ukrainy, 2015). The Law of Ukraine «On Public Procurement» (Law Ukrainy, 2015) does not apply the rule of two manufacturers in any article. The word «manufacturer» is mentioned only in paragraph 3 of Part 2 of Art. 22 of the Law of Ukraine «On Public Procurement» (Law Ukrainy, 2015), namely it is forbidden in the technical documentation to make reference to a specific trademark or company, patent, design or type of the object of purchase, the source of its origin or manufacturer.

Analysis of recent researches and publications. The following scientists worked on issues of authority of the Antimonopoly Committee of Ukraine and the Permanent Administrative Collegium of the Antimonopoly Committee of Ukraine: Y. Zhuryk (Zhuryk, 2004), R. Mikhailik (Mikhalik, 2011), O. Pidmogilny (Pidmogilny, 2012), V. Gladka (Gladka, 2014), M. Malyuk (Malyuk, 2015), A. Zagrebelskaya (Zagrebelskaya, 2018).

However, the powers of the Permanent Administrative Board of the Antimonopoly Committee of Ukraine in the field of public procurement have not been thoroughly investigated in terms of interpreting the rules. Ukrainian science is actively developing regulations on public procurement and the limits of the powers of appeal bodies. There has been no comprehensive study of the mandate of the Permanent Administrative Board of the Antimonopoly Committee of Ukraine in the field of public procurement.

Presenting main material. A. Zagrebelskaya described in detail the rule of «two manufacturers» (Zagrebelskaya, 2018). In the mentioned article A. Zagrebelska also gave an example of a table for proving at a meeting of the Collegium that the products of at least two manufacturers, represented in Ukraine, meet all the requirements of the tender documentation.

The essence of the «two manufacturers» rule is that the Board invites the Customer to provide «... information on the compliance of all in the aggregate with the requirements of the tender documentation for the products of at least two manufacturers with supporting documents» (See the Board's decision in cases: UA-2018-07-06-001322-c.b1, UA-2018-10-26-000565-b.a1, UA-2019-02-19-000276-c.c2, UA-2018-06-07-003278-a.b2, UA-2018-06-05-002268-a.c3 and other).

In case the Customer has not proved the existence of the products of two manufacturers, which are represented in Ukraine, the Board shall make changes to the tender documentation.

However, in our opinion, the Board has replaced the concepts that are enshrined in the Law of Ukraine «On Public Procurement». As an argument can be cited: Part 2 of Art. 20 of the Law of Ukraine «On Public Procurement» of December 25, 2015 
№ 922-VIII stipulates that during the open tender procedure all tenderers have the right to submit tenders. At least two proposals must be submitted for the procurement procedure. In the Law of Ukraine «On Public Procurement» of December 25, 2015, № 922-VIII, no article applies the rule of two manufacturers. The word «manufacturer» is mentioned only in paragraph 3 of Part 2 of Article 22 of the Law of Ukraine «On Public Procurement», namely it is forbidden in the technical documentation to make reference to a specific trademark or company, patent, design or type of the object of purchase, source of its origin or manufacturer.

In the legislation of the European Union and Ukraine, a manufacturer is understood to mean an economic entity that manufactures a product or declares itself as a producer of a product (Article 2 of Regulation (EC) 765/2008 of 9 July 2008 establishing requirements for accreditation and market surveillance relating to the sale of products and repealing Regulation (EEC) № 339/93; Article 2 of Directive 2010/35 / EC of the European Parliament and of the Council of 16 June 2010 on mobile pressure equipment, and repealing Council Directives 76/767 / EEC, 84/525 / EEC, 84/526 / EEC, 84/527 / EEC and 1999/36 / EC; Article 1 of the Law of Ukraine «On Consumer Protection» of 12.05.1991 № 1023-XII; Article 1 of the Law of Ukraine «On Liability for Damage Caused as a result of a defect in products «dated May 19, 2011 № 3390-VI and others).

However, economic activity is not only in the manufacture of products, but also in its implementation (Part 1, Article 3 of the Economic Code of Ukraine). According to Art. 263 of the Economic Code of Ukraine economic and commercial activity in the field of commodity circulation, which is aimed at the sale of products for industrial and technical purposes and consumer goods is carried out by economic entities. Economic entity means the participants of economic relations who carry out economic activities, realizing economic competence (set of economic rights and obligations), have separate property and are responsible for their obligations within this property, except in cases provided by law (55 (1) of the the Economic Code of Ukraine). Part 2 of Art. 55 of the Commercial Code of Ukraine refers to economic entities and economic organizations and citizens of Ukraine, foreigners and stateless persons who carry out business activities and are registered as entrepreneurs under the law. An analysis of the current legislation of Ukraine and the EU Directives makes it possible to state that any entity can participate in public procurement. Yes, paragraph 35 of Part 1 of Art. 1 of the Law of Ukraine «On Public Procurement» of December 25, 2015 № 922-VIII states that a tenderer may be a natural person, including a natural person an entrepreneur, legal entity (resident or non-resident) who submitted a tender or took participation in negotiations in the case of the procurement negotiated procedure. The same is stated in paragraph 11 of the Preamble to Directive 2014/24 / EC of the European Parliament and of the Council of 26 February 2014 on public procurement and repeal of Directive 2004/18 / EC - «Tenderer» means an entity which has 
submitted competitive bid. Point 14 of the Preamble to Directive 2014/24 / EC of the European Parliament and of the Council of 26 February 2014 on public procurement and repeal of Directive 2004/18 / EC and point 17 of the Preamble of Directive 2014/25 / EC of the European Parliament and of the Council of 26 February 2014 on the procurement of entities operating in the fields of water, energy, transport and postal services, which terminates Directive 2004/17 / EC, state that the term «economic operator» should be interpreted broadly, including any individuals and / or organizations that offer виконання performing works, supplying products or providing services on the market, regardless of their organizational form of activity. Thus, firms, branches, subsidiaries, partnerships, cooperatives, limited liability companies, universities, public or private, or other forms of non-physical entity, all fall within the concept of an entity, whether or not they are considered they are «legal entities» in all circumstances.

Contrary to these norms, the Board artificially restricts the range of potential bidders only to producers of products. As a consequence, non-product participants or participants who do not have direct contractual relations with manufacturers and / or their representative offices are excluded from the procurement procedure.

The illegality of the Board's position on the two manufacturers is also indicated in the decisions of the Kyiv District Administrative Court of May 15, 2019 No. 640/20251/18 (consideration of the complaint of DIAVITA Limited Liability Company No. 672 of 10.10 .2018 in the procurement of UA-2018 -09-13-001220-c) and on August 5, 2019 No. 640/9921/19 (consideration of the complaint of Limited Liability Company «Etalon Auto Trading House» dated 14.04.2019 No. 574 in the procurement UA-2019-04-05- 000260-a.c2). The Court noted that the Antimonopoly Committee of Ukraine did not carry out a complete and objective analysis of the circumstances of the complaints in terms of establishing discriminatory conditions regarding the characteristics of the goods, and decisions were made only on the basis that the characteristics of the procurement subject established by the customer in the tender documentation, the products of two manufacturers, which are represented in Ukraine. The Kyiv District Administrative Court, based on an analysis of the current legislation, stated that «... not only two manufacturers should exist, but they must submit a bid and participate in the relevant tender.

Conclusion. Considering the above, we can conclude that the Permanent Administrative Board of the Antimonopoly Committee of Ukraine is unlawful. The Board, by introducing the «two manufacturers» rule, artificially limited the range of potential bidders to only manufacturers of products. In this regard, non-product participants or participants who do not have direct contractual relations with manufacturers and / or their representative offices are excluded from the procurement procedure. 


\section{REFERENCES}

1.Gladka, V.V. (2014). Procesualnuy status organiv Antimonopolnogo komitetu Ukrainu v spravah pro poshurenny informatsii, sho vodud v omanu// Pravo: istorija, teorija, praktik. Materialu mizhnarodnoji naukovo-praktichnoi konferencii (m. Lviv, 14-15 berezny, 2014). - Herson: vudavnuchuy dim «Gelvetika», P.115.

2.Zagrebelskaya, A. (2018). Pravulo dvoh vurobnukiv: mifu ta realnist [The rule of «two manufacturers»: myths and reality]. Retrieved from //https://radnuk.com.ua/ publications/articles/articles-1_11004.html. [in Ukrainian]

3.Zakon Ukrainy «Pro publichni zakupivli» № 922-VIII vid 25.12.2015 [Law of Ukraine «On Public Procurement»](n.d.) zakon.rada.gov.ua. Retrieved from https://zakon.rada.gov.ua/laws/show/922-19[in Ukrainian].

4.Zhurik, Y. (2004). Rozglyd Antumonopolnim komitetom Ukrainu sprav pro porushenny zakonodavstva pro zahust ekonomichnoi konkyrentcii(2004) : avtoref dis. na zdobuttya naukovogo stupenya kandidatayurid. nauk: 12.00.04. Kyiv. nats. un-t imeni Tarasa Shevchenka. Kyiv, 23 p.

5.Maluk, M.O. (2015). Aktualni problemy diylnosti Antumonopolnogo Komitetu Ukrainy. Naukovuy visnuk Uzhgorodskogo natsionalnogoUniwersutetu/ Seria pravo. Tom 33. P. 47-53.

6.Michailik, R.R. (2011). Derzhavni zakupivli: Naukovo- praktuchuy komentar do zakonu Ukrainy «Pro zdiysnenny derzhavnuh zakupivel». Tom 1: Zagalni polozhenny; Derzhavne reguluvanny ta control u sferi zakupivel; Zagalni umovu zdiysnenny derzhavnuh zakupivel / Michailik R.R., Vernugora O.O. - K.: Globalkonsaltung Ukraina, P. 241-242.

7.Pidmogilny, O.O. (2012). Mehanizm ta porydok oskarzhenny porushen u sferi derzhavnuh zakupivel v Ukraini. Ekonomika ta derzhava. № 5. P. 144-148. 